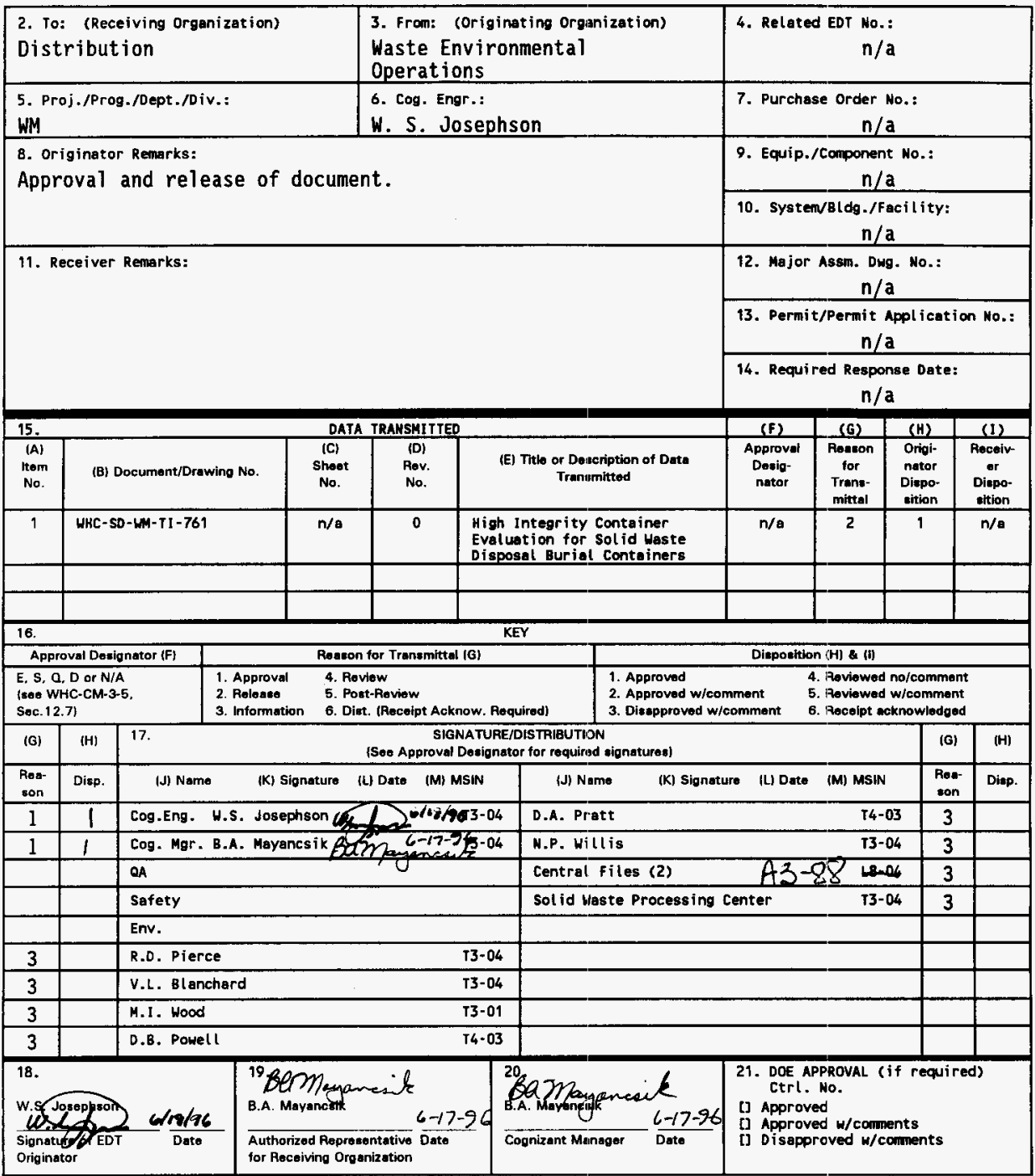

BD-7400-172-2 (06/94) GEF097 


\title{
High Integrity Container Evaluation for Solid Waste Disposal Burial Containers
}

\author{
W.S. Josephson \\ WHC, Richland, WA 99352 \\ U.S. Department of Energy Contract DE-AC06-87RL10930 \\ EDT/ECN: EDT-609636 \\ Org Code: 87610 \\ B\&R Code: YNO100000 \\ UC: 2020 \\ Charge Code: ML439 \\ Total Pages: 35
}

Key Words: High Integrity Container, HIC, NRC, Category 3 Waste, Cat 3, Evaluation

Abstract: This document summarizes the evaluation of various containers that can be used for the disposal of Category 3 waste in the Low Level Burial Grounds. These containers include the VECTRA reinforced concrete HIC, reinforced concrete culvert, and the reinforced concrete vault. This evaluation provides justification for the use of these containers and identifies the conditions for use of each.

TRADEMARK DISCLAImER. Reference herein to any specific comercial product, process, or service by trade nane, trodemark, manufacturer, or otherwise, does not necessarily constitute ior imply its endorsement, reconvendation, or favoring by the United states Government or any agency thereof or its contractors or subcontractors.

Printed in the United States of Mmerica. To obtoin copies of this docunent, contact: WHC/BCS Document Control Services, P.O. BoX 1970, Mailstop H6-138, Richland wA 99352, Phone (509) 372-2420; Fax (509) 376-4989.
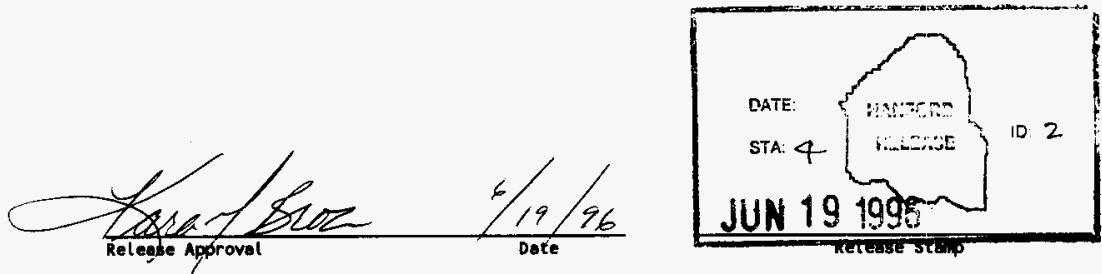

Approved for Public Release 
WHC-SD-WM-TI-761 Rev. 0

High Integrity Container Evaluation for Solid Waste Disposal Burial Containers

\author{
Prepared by: \\ W. S. Josephson \\ Westinghouse Hanford Company \\ May 1996
}


WHC-SD-WM-TI-761 Rev. 0

Intentionally Blank 


\section{WHC-SD-WM-TI-761 Rev. 0}

Table of Contents

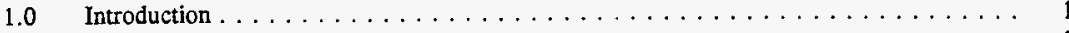

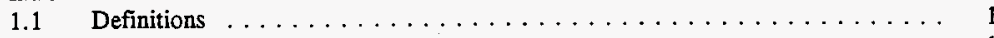

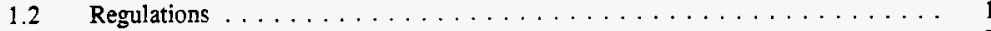

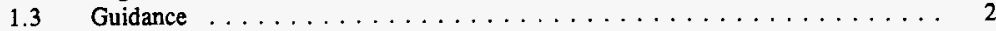

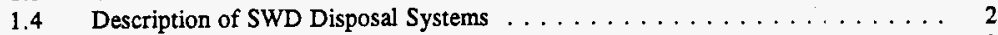

1.4.1 VECTRA Reinforced Concrete HIC . . . . . . . . . . . . . 2

1.4 .2 Reinforced Concrete Culvert . . . . . . . . . . . . 2

1.4.3 Reinforced Concrete Vault $\ldots \ldots \ldots \ldots \ldots \ldots \ldots$

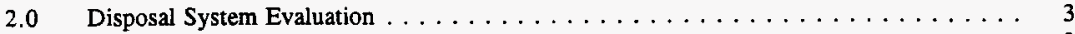

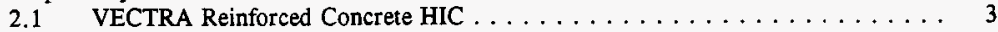

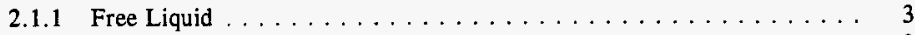

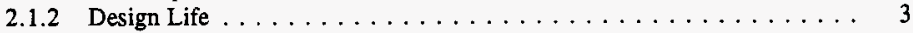

2.1.3 Corrosive and Chemical Effects ................. 4

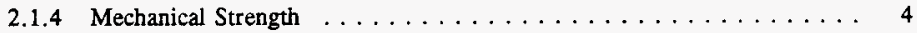

2.1.5 Thermal Resistance ..................... 5

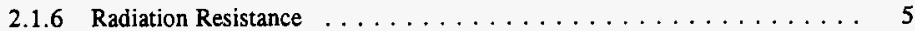

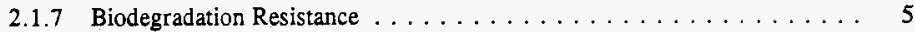

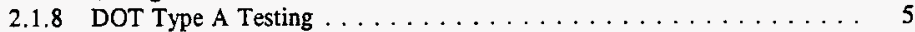

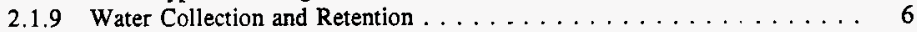

2.1 .10 Closure System . . . . . . . . . . . . . . . . . 6

2.1 .11 Prototype Testing . . . . . . . . . . . . . . . . 6

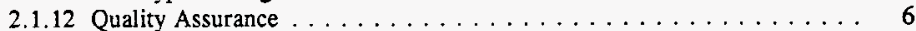

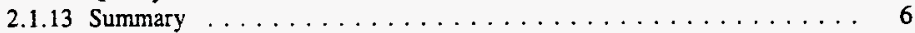

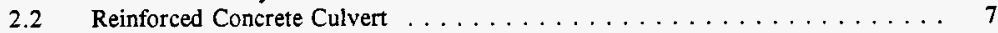

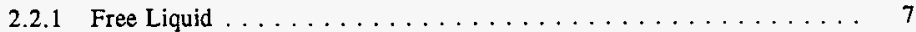

2.2 .2 Design Life . . . . . . . . . . . . . . . . . 7

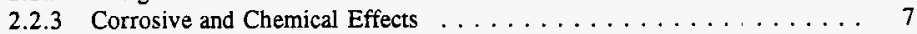

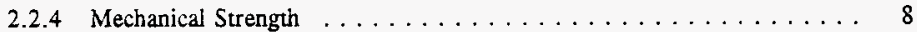

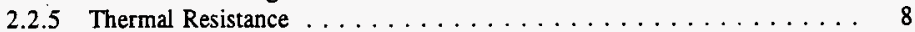

2.2 .6 Radiation Resistance $\ldots \ldots \ldots \ldots \ldots \ldots \ldots \ldots \ldots$

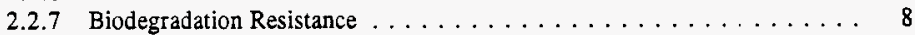

2.2 .8 DOT Type A Testing . . . . . . . . . . . . . . . . . . 9

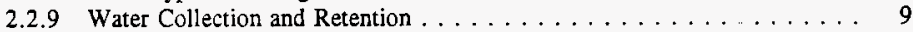

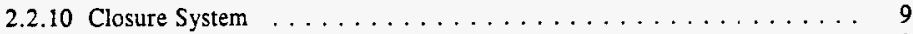

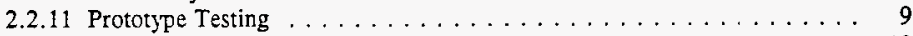

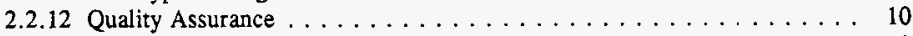

2.2 .13 Summary . . . . . . . . . . . . . . . . . . 10

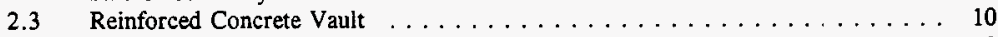

2.3 .1 Free Liquid . . . . . . . . . . . . . . . . . 10

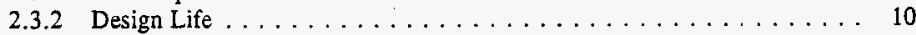

2.3.3 Corrosive and Chemical Effects $\ldots \ldots \ldots \ldots \ldots \ldots \ldots \ldots \ldots$

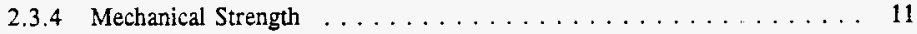

2.3.5 Thermal Resistance . . . . . . . . . . . . . . . . . 11

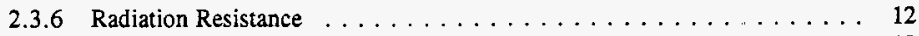

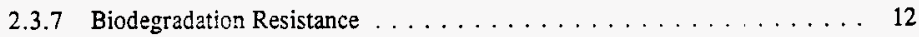

2.3 .8 DOT Type A Testing . . . . . . . . . . . . . . . . . . 12

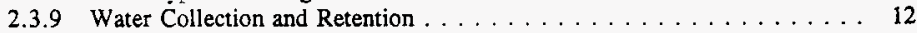


WHC-SD-WM-TI-761 Rev. 0

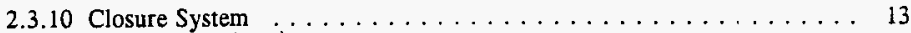

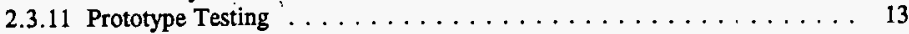

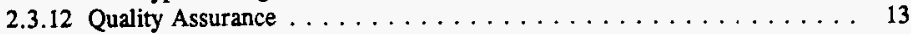

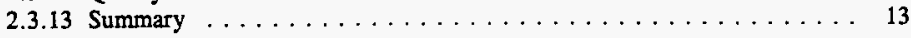




\section{WHC-SD-WM-TI-761 Rev. 0}

\section{High Integrity Container Evaluation for}

Solid Waste Disposal Burial Containers

\subsection{Introduction}

In order to provide radioactive waste disposal practices with the greatest measure of public protection, Solid Waste Disposal (SWD) adopted the Nuclear Regulatory Commission (NRC) requirement to stabilize high specific activity radioactive waste prior to disposal. Under NRC guidelines, stability may be provided by several mechanisms, one of which is by placing the waste in a high integrity container (HIC). During the implementation process, SWD found that commercially-available HICs could not accommodate the varied nature of weapons complex waste, and in response developed a number of disposal containers to function as HICs. This study evaluates the disposal containers in use by SWD for compliance with the NRC HIC requirements and justifies their use.

\subsection{Definitions}

The NRC defines high specific activity waste as Class B and C waste determined in aicordance with 10 CFR 61.55. The NRC classification system is designed to service the commercial nuclear power industry, and as a result has a short list of radionuclides of concern which commonly occur in power plant waste. The weapons complex waste disposed by SWD contains a greater variety of radionuclides, and therefore required a different classification system. SWD defines high specific activity waste as Category 3 waste classified in accordance with. WHC-EP-0063, Hanford Site Solid Waste Acceptance Criteria (Reference a). Both systems, however, require stabilization of high specific activity waste.

The NRC defines HICs as those containers whose design and construction have passed a rigorous technical evaluation by the Low Level Waste (LLW) Management Branch, and have been officially approved for stabilization of Class B and C waste. SWD defines HICs as those containers whose design and construction have passed a rigorous technical evaluation and have been officiaily approved for stabilization of Category 3 waste.

\subsection{Regulations}

The legal requirements for high integrity containers are found in 10 CFR 61 . These general requirements are intended to minimize the access of water to the waste by providing stability, which in turn reduces migration of radionuclides, long-term disposal site maintenance, and the potential exposure to intruders after the institutional control period. The 10 CFR 61 stability requirements for high specific activity waste are listed below:

To the extent that it is practicable, Class B and C waste forms or containers should be designed to be stable, i.e. maintain gross physical properties and identity, over 300 years ${ }^{1}$.

Waste must have structural stability. A structurally stable waste form will generally maintain its physical dimensions and its form, under the expected disposal conditions such as weight of overburden and compaction equipment, the preserice of moisture and microbial activity, and internal factors such as radiation effects and chemical changes. Structural stability can be provided by the waste form itself, processing the waste into a stable form, or placing the

${ }^{1} 10$ CFR $61.7(b)$ (2) 
WHC-SD-WM-TI-761 Rev. 0

waste into a disposal container or structure that provides stability after disposal ${ }^{2}$.

\subsection{Guidance}

The NRC realized that the $10 \mathrm{CR} 61$ requirements are very general in nature and are not particularly useful in designing, fabricating, or using HICs. To help alleviate this problem, the NRC LLW Management Branch developed a Technical Position on Waste Form (Reference b), which contains detailed engineering and technical guidance to help container manufacturers, waste generators, and disposal facilities meet the intent of 10 CFR 61 . Such guidance is not a regulatory requirement, but instead represents one possible way of meeting 10 CFR 61 regulations.

Since the NRC technical staff evaluates manufacturer's HIC designs on a regular basis, a body of NRC technical papers is also available to provide evaluation methodology and technical information. One technical paper was particularly useful to this study, and is included as NRC Technical Evaluation Report "Multi-Use Container - High Integrity Container" (Reference c).

\subsection{Description of SWD Disposal Systems}

A brief description of the SWD disposal containers evaluated in this study are includecl in this section.

\subsubsection{VECTRA Reinforced Concrete HIC}

VECTRA Reinforced Concrete HICs are constructed of conventionally reinforced concrete. The concrete mixture contains sulfate-resistant portland cement, fly ash, and graded aggregates. High range water reducers were used to minimize the water-cement ratio in order to obtain a strong, low permeability concrete. Reinforcement is provided by a standard rebar cage. The final structure is coated on the interior and exterior surfaces with an epoxy-based sealing compound. The VECTRA HIC is a right circular cylindrical container designed to overpack a total of 95 standard 55-gal drums of Category 3 waste for disposal. The payload volume of a VECTRA HIC measures 11 feet in diametci by 16 feet tall, with a wall thickness of 12 inches. They are delivered in 4 sections (bottom slab, cylindrical risers, top slab) and assembled in the field before and after waste loading. Epoxybased adhesives are used during assembly to provide positive sealing. VECTRA HICs are designed for direct burial, with a minimum soil cover of 5 meters. They are designed for suspended lifting, with lifting attachments provided on the interior wall of the cylindrical risers and on the top surfaces of the top and bottom slabs. VECTRA HICs were procured using WHC-HS-V-P-0036 (Reference d).

\subsubsection{Reinforced Concrete Culvert}

Reinforced concrete culverts are constructed of steel fiber reinforced concrete. The concrete mixture contains sulfate-resistant portland cement, fly ash, graded aggregates, and steel fiber reinforcement. High range water reducers were used to minimize the water-cement ratio in order to obtain a strong, low permeability concrete. Structural reinforcement is provided by a standard rebar cage. The final structure is coated on the exterior surface with an epoxy-based sealing compound. The reinforced concrete culvert is a right circular cylindrical container designed to overpack remote-handled Category 3 waste packaged using the Hittman liner system for disposal. It may also be used to overpack other Category 3 waste. The payload volume of a culvert measures 6 feet in diameter by 6 feet tall, with a top slab thickness of 24 inches, a bottom slab thickness of 12 inches, and a wall thickness of 8 inches. They are delivered in 2 sections (container body, top siab) and are assembled in the field arter waste

210 CFR $61.56(b)(1)$ 


\section{WHC-SD-WM-TI-761 Rev. 0}

loading. For remote-handled waste, no adhesives are used during assembly to minimize personnel exposure. For contact-handled waste, epoxy-based adhesives are used during assembly to provide positive sealing. Reinforced concrete culverts are designed for direct burial, with a minimum soil cover of 5 meters. They are designed for suspended lifting, with lifting attachments provided on the interior wall of the container body and on the top surface of the top slab. The culverts were procured using a series of statements of work, the most recent of which is attached as Appendix A.

\subsubsection{Reinforced Concrete Vault}

Reinforced concrete vaults are constructed of steel fiber reinforced concrete. The concrete mixture contains sulfate-resistant portland cement, fly ash, graded aggregates, and steel fiber reinforcement. High range water reducers were used to minimize the water-cement ratio in order to obtain a strong, low permeability concrete. Structural reinforcement is provided by a standard rebar cage. The final structure is coated on the exterior surface with an epoxy-based sealing compound. The reinforced concrete vault is a rectangular container designed to overpack Category 3 waste for disposal. The payload volume of a vault measures 10.5 feet long by 7 feet wide by 9.5 feet tall, with a top slab thickness of 11 inches, a bottom slab thickness of 9 inches and an average wall thickriess of 8 inches. They are delivered in 3 sections (container body, rectangular riser, top slab) and assembled in the field after waste loading. For remote-handled waste, no adhesives are used during assembly to minimize personnel exposure. For contact-handled waste, epoxy-based adhesives are used during assembly to provide positive sealing. Reinforced concrete vaults are designed for direct burial, with a minimum soil cover of 5 meters. They are designed for suspended lifting, with lifting attachments provided on the interior wall of the container body and on the top surface of the top slab. The vaults were procured using a statement of work, which is attached as Appendix B.

\subsection{Disposal System Evaluation}

Each disposal container described in Section 1.4 was evaluated against the regulatory requirements for HICs in 10 CFR 61 and the NRC HIC guidance in Technical Position on Waste Form (Peference b). The results of each evaluation are summarized in this section.

\subsection{VECTRA Reinforced Concrete HIC}

A discussion of VECTRA HIC compliance with NRC requirements and guidance is included in this section.

\subsubsection{Free Liquid}

Free liquids are prohibited from disposal in the LLBG by WHC-EP-0063 (Reference a), and by extension are prohibited from disposal in the VECTRA HICs. Therefore, the VECTRA HIC was considered to meet the free liquid requirements in Technical Position on Waste Form Section 4,a (Reference b).

\subsubsection{Dasign Life}

Technical Position on Waste Form (Reference b) and NRC Technical Evaluation Report "Muiti-Use Container - High Integrity Container" (Reference c) specify a design lifetime of 300 years. VECTRA 95 Drum CHIC Design Report (Reference e) details the myriad design features incorporated to meet the 300 year design life goal. Each of these features are discussed in greater detail in following sections and are not duplicated here. Taken together, these features produced a design life as long as 


\section{WHC-SD-WM-TI-761 Rev. 0}

is reasonably achievable, and which should be wiil in excess of the 300 year goal. Therefore, the VECTRA HIC was considered to meet the design life requirements in Technical Position on Waste Form (Reference b) Section 4.b.

\subsubsection{Corrosive and Chemical Effects}

The VECTRA HIC design considered corrosive and chemical effects from both the waste contents and the disposal environment. Since most chemicals which are detrimental to concrete are liquid and/or hazardous, and as a result are excluded from the LL.BG by WHC-EP-0063 (Reference a), the radioactive waste contents pose little danger to the VECTRA HIC. In addition, the interior surfaces of the VECTRA HICs are coated with an epoxy sealant which has demonstrated superior chemical resistance. The interior coating was not considered necessary for corrosion and chemical resistance, but it offers an additional measure of protection from the waste contents.

The greatest threat to the VECTRA HIC was from disposal environment agents, specifically ground water with dissolved sulfates, oxygen, and chlorides. The container was protected against these agents by the following design features:

1. Sulfate-resistant Type I/II portland cement was used to limit sulfate attack.

2. Class F fly ash was included in the concrete mix to increase concrete density and improve resistance to sulfate attack.

3. A low water-cement ratio concrete mixture was used, which provides high density, low permeability concrete. Low permeability helps prevents sulfate attack on the concrete matrix and corrosion of encased reinforcement.

4. Only low chloride concrete mix constituents were used, to minimize the free chloride available to react with encased rebar.

5. Concrete cover of 1.5 inches was provided for all encased rebar, which limits access of water, oxygen and chloride to any steel structural components.

6. Exterior surfaces of the concrete were coated with an epoxy sealant to limit migration of water and dissolved chemicals through the concrete.

7. Development of micro-cracks in the concrete matrix was minimized by proper consolidation of the concrete, moist curing, and mechanical strength overdesign.

Taken together, these design features produced a highly degradation-resistant structure. Therefore, the VECTRA HIC was considered to meet the corrosion and chemical resistance requirements in Technical Position on Waste Form (Reference b) Section 4.c.

\subsubsection{Mechanical Strength}

The VECTRA HIC design considered static loads from soil overburden, grout fill and soil backfill, as well as dynamic loads from waste handling, and disposal site operations. The VECTRA HIC was designed in accordance with Uniform Building Code (UBC) requirements for reinforced concrete structures, which produced a robust design with significant safety margins. Therefore, the VECTRA HIC was considered to meet the mechanical strength requirements in Technical Position on Waste Form (Reference b) Section 4.d. 


\subsubsection{Thermal Resistance}

The VECTRA HIC design considered the effects of thermal loads. A thermal cycling test program was conducted by the manufacturer on the construction materials, and showed no significant changes in concrete design properties following thermal cycling. Therefore, the VECTRA HIC was considered to meet the thermal resistance requirements in Technical Position on Waste Form (Reference b) Section 4.f.

\subsubsection{Radiation Resistance}

The VECTRA HIC design considered the radiation stability of the container materials. Appendix A, Section II.D of Technical Position on Waste Form (Reference b) discusses previous irradiation testing results on concrete materials. Such testing has shown no significant changes in concrete design properties at exposure levels past $10^{8}$ Rads. As a result, additional irradiation testing was not required for the concrete.

The epoxy coating material was also selected for resistance radiation exposure. The epoxy manufacturer's radiation testing data has shown no significant changes in design properties at exposure levels up to $10^{8}$ Rads. As a result, additional irradiation testing was not required for the epoxy coating material. Taken together, the existing irradiation testing data clearly demonstrate the radiation resistance of the VECTRA HIC design. Therefore, the VECTRA HIC was considered to meet the radiation resistance requirements in Technical Position on Waste Form (Reference b) Section 4.g.

\subsubsection{Biodegradation Resistance}

The VECTRA HIC design considered the biodegradation properties of the container materials. Appendix A, Section II.E of Technical Position on Waste Form (Reference b) discusses previous biodegradation testing results on concrete materials. Such testing has shown no significant changes in design properties following exposure to microorganisms in accordance with ASTM G21 and G22.

There are, however, several classes of microorganisms which have been shown to degrade concrete by giving off acidic waste products. Unfortunately, no standard test method exists to quantify the effects of such microorganisms. To minimize the potential for damage to the VECTRA HIC by all microorganisms, the organic carbon content in the cement matrix was limited to $1 \%$. By limiting the potential food source in the concrete matrix, the growth of rnicroorganisms in the vicinity of the cement matrix will be strictly limited. Furthermore, the corcrete will be shielded from any acidic waste products by the epoxy coating. Therefore, the VECTRA HIC was considered to meet the biodegradation resistance requirements in Technical Position on Waste Form (Reference b) Section 4.h.

\subsubsection{DOT Type A Testing}

Since the VECTRA HIC will be used as a disposal container only, DOT Type A testing was waived by WHC-HS-V-P-0036 (Reference d). As a result, the VECTRA HIC does not meet the DOT Type A requirements in Technical Position on Waste Form (Reference b) Section 4.i. As discussed in Section 2.1.13, restrictions were placed on VECTRA HIC use for stabilization of Category 3 waste to account for this shortcoming. 


\subsubsection{Water Collection and Retention}

The VECTRA HIC was designed to avoid collection and retention of water on its top surfaces. As described in VECTRA 95 Drum CHIC Design Report (Reference e) and VECTRA drawing 7148100 , the VECTRA HIC lid is flat. Therefore, the VECTRA HIC was considered to meet the water collection and retention requirements in Technical Position on Waste Form (Reference b) Section 4.k.

\subsubsection{Closure System}

The VECTRA HIC was designed to provide positive closure by sealing all joints with an epoxy-based adhesive. It does not, however, allow for inspection of the contents or for use of a vent to release gas generated by the waste. As a result, the VECTRA HIC does not meet the closure system requirements in Technical Position on Waste Form (Reference b) Section 4.l. As discussed in Section 2.1.13, restrictions were placed on VECTRA HIC use for stabilization of Category 3 waste to account for this shortcoming.

\subsubsection{Prototype Testing}

Prototype testing was waived by WHC-HS-V-P-0036 (Reference d). As a result the VECTRA HIC does not meet the prototype testing requirements in Technical Position on Waste Form (Reference b) Section 4.m.

However, as discussed in Section 4.6.9 of NRC Technical Evaluation Report "Multi-Use Container High Integrity Container" (Reference c), the principal reason the NRC requires prototype testing for HICs is to support DOT Type A qualification. This is because the response of a container to complex dynamic loads incurred during drop testing and other accident scenarios is exceedingly difficult to model. Loading of concrete structures under burial conditions, on the other hand, can be accurately modeled and is supported by a wealth of past design experience. Therefore, satisfactory mechanical strength was considered to be adequately demonstrated by conservative engineering design alone.

\subsubsection{Quality Assurance}

VECTRA HICs are manufactured under VECTRA's quality assurance program. The VECTRA QA program meets the stringent requirements of NQA-1, and is fully approved by WHC. Therefore, the VECTRA HIC was considered to meet the quality assurance requirements in Technical Position on Waste Form (Reference b) Section 4.n.

\subsubsection{Summary}

The VECTRA HIC is considered approved as a HIC provided that the following restrictions are followed:

1. The VECTRA HIC shall be used as a disposal container only, and will not be used to transport radioactive materials of any type.

2. Wastes which require subsequent inspections of any type shall not be placed in the VECTRA HICs.

3. Gas generating waste will be evaluated on a case-by-case basis. 


\subsection{Reinforced Concrete Culvert}

A discussion of reinforced concrete culvert compliance with NRC requirements and guidance is included in this section.

\subsubsection{Free Liquid}

Free liquids are prohibited from disposal in the LLBG by WHC-EP-0063 (Reference a), and by extension are prohibited from disposal in the culverts. Therefore, the culvert was considered to meet the free liquid requirements in Technical Position on Waste Form (Reference b) Section 4.a.

\subsubsection{Design Life}

Technical Position on Waste Form (Reference b) and NRC. Technical Evaluation Report "Multi-Use Container - High Integrity Container" (Reference c) specify a design lifetime of 300 years. The culvert statement of work in Appendix A details the myriad design features incorporated to meet the 300 year design life goal. Each of these features are discussed in greater detail in following sections and are not duplicated here. Taken together, these features produced a design life as long as is reasonably achievable, and which should be well in excess of the 300 year goal. Therefore, the culvert was considered to meet the design life requirements in Technical Position on Waste Form (Reference b) Section 4.b.

\subsubsection{Corrosive and Chemical Effects}

The culvert design considered corrosive and chemical effects from both the waste contents and the disposal environment. Since most chemicals which are detrimental to concrete are liquid and/or hazardous, and as a result are excluded from the LLBG by WHC-EP-0063 (Reference a), the radioactive waste contents pose little danger to the culvert.

The greatest threat to the culvert was from disposal environment agents, specifically ground water with dissolved sulfates, oxygen, and chlorides. The container was protected against these agents by the following design features:

1. Sulfate-resistant Type I/II portland cement was used to limit sulfate attack.

2. Class $\mathrm{F}$ fly ash was included in the concrete mix to increase concrete density and improve resistance to sulfate attack.

3. A low water-cement ratio concrete mixture was used, which provides high dersity, low permeability concrete. Low permeability helps prevents sulfate attack on the concrete matrix and corrosion of encased reinforcement.

4. Only low chloride concrete mix constituents were used, to minimize the free chloride available to react with encased rebar.

5. Concrete cover of 2 inches was provided for all encased rebar, which limits access of water, oxygen and chloride to any steel structural components.

6. Exterior surfaces of the concrete were coated with an epoxy sealant to limit migration of water and dissolved chemicals through the concrete. 
WHC-SD-WM-TI-761 Rev. 0

7. Air entrainment was added to improve sulfate and freeze-thaw resistance of the concrete.

8. Development of micro-cracks in the concrete matrix was minimized by use of steel fiber reinforcement, proper consolidation of the concrete, moist curing, and mechanical strength overdesign.

Taken together, these design features produced a highly degradation-tesistant structure. Therefore, the culvert was considered to meet the corrosion and chemical resistance requirements in Technical Position on Waste Form (Reference b) Section 4.c.

\subsubsection{Mechanical Strength}

The culvert design considered static loads from soil overburden and backfill, as well as dynamic loads from waste handling, and disposal site operations. The culvert was designed in accordance with Uniform Building Code (UBC) requirements for reinforced concrete structures, which produced a robust design with significant safety margins. Therefore, the culvert was considered to meet the mechanical strength requirements in Technical Position on Waste Form (Reference b) Section 4.d.

\subsubsection{Thermal Resistance}

The culvert design considered the effects of thermal loads. Section 4.6 .6 of NRC Technical Evaluation Report "Multi-Use Container - High Integrity Container" (Reference c) discusses previous thermal cycling test results on concrete materials. Such testing has shown no significant changes in concrete design properties following thermal cycling, and as a result, additional thermal cycling testing was not required for the concrete.. Therefore, the culvert was considered to meet the thermal resistance requirements in Technical Position on Waste Form (Reference b) Section 4.f:

\subsubsection{Radiation Resistance}

The culvert design considered the radiation stability of the container materials. Appenijix A, Section II.D of Technical Position on Waste Form (Reference b) discusses previous irradiation testing results on concrete materials. Such testing has shown no significant changes in concrete design properties at exposure levels past $10^{8}$ Rads. As a result, additional irradiation testing was not required for the concrete.

The epoxy coating material was also selected for resistance radiation exposure. The epoxy manufacturer's radiation testing data has shown no significant changes in design properties at exposure levels up to $10^{8}$ Rads. As a result, additional irradiation testing was not required for the epoxy coating material. Taken together, the existing irradiation testing data clearly demonstrate the radiation resistance of the culvert design. Therefore, the culvert was considered to meet the radiation resistance requirements in Technical Position on Waste Form (Reference b) Section 4.g.

\subsubsection{Biodegradation Resistance}

The culvert design considered the biodegradation properties of the container materials. Appendix A, Section II.E of Technical Position on Waste Form (Reference b) discusses previous bicidegradation testing results on concrete materials. Such testing has shown no significant changes in design properties following exposure to microorganisms in accordance with ASTM G21 and G22.

There are, however, several classes of microorganisms which have been shown to degrade concrete by giving off acidic waste products. Unfortunately, no standard test method exists to quantify the 
effects of such microorganisms. To minimize the potential for damage to the culvert by all microorganisms, the organic carbon content in the cement matrix was limited to $1 \%$. By limiting the potential food source in the concrete matrix, the growth of microorganisms in the vicinity of the cement matrix will be strictly limited. Furthermore, the concrete will be shielded from any acidic waste products by the epoxy coating. Therefore, the culvert was considered to meet the biodegradation resistance requirements in Technical Position on Waste Form (Reference b) Section 4.h.

\subsubsection{DOT Type A Testing}

Since the culvert will be used as a disposal container only, DOT Type A testing was waived by the culvert statement of work in Appendix A. As a result, the culvert design does not meet the DOT Type A requirements in Technical Position on Waste Form (Reference b) Section 4.i. As discussed in Section 2.2.13, restrictions were placed on culvert use for stabilization of Category 3 waste to account for this shortcoming.

\subsubsection{Water Collection and Retention}

The culvert was designed to avoid collection and retention of water on its top surfaces. As shown in Appendix A, the culvert lid is flat. Therefore, the culvert was considered to meet the water collection and retention requirements in Technical Position on Waste Form (Reference b) Section 4.k.

\subsubsection{Closure System}

For remote-handled waste, the culvert lid is not sealed with epoxy-based adhesive. As a result, the culvert does not meet the closure system requirements in Technical Position on Waste Form (Reference b) Section 4.1. Use of epoxy-based adhesive is not required for remote-handled waste in order to minimize personnel exposure. Given the low soil moisture content in Hanford soil and the geometry of the container, there is very little potential for water infiltration through the unsealed joint. The potential threat from release of radionuclides due to this limited water infiltration was considered to be far less that the threat from personnel exposure during sealing operations. Therefore, no restrictions associated with sealing were placed on culvert use for stabilization of remote-handled Category 3 waste.

For contact-handled waste, the culvert was designed to provide positive closure by sealing all joints with an epoxy-based adhesive, but does not allow for inspection of the contents or for use of a vent to release gas generated by the waste. As a result, the culvert does not meet the closure sistem requirements in Technical Position on Waste Form (Reference b) Section 4.I. As discussed in Section 2.2.13, restrictions were placed on culvert use for stabilization of Category 3 waste to account for this shortcoming.

\subsubsection{Prototype Testing}

Prototype testing was waived by Appendix A. As a result the culvert does not meet the prototype testing requirements in Technical Position on Waste Form (Reference b) Section 4.m.

However, as discussed in Section 4.6.9 of NRC Technical Evaluation Report "Multi-Use Container High Integrity Container" (Reference c), the principal reason the NRC requires prototype testing for HICs is to support DOT Type A qualification. This is because the response of a container to complex dynamic loads incurred during drop testing and other accident scenarios is exceedingly difficult to model. Loading of concrete structures under burial conditions, on the other hand, can be accurately 
modeled and is supported by a wealth of past design experience. Therefore, satisfactory mechanical strength was considered to be adequately demonstrated by conservative engineering design alone.

\subsubsection{Quality Assurance}

The culvert manufacturer was not required to maintain a quality assurance program meeting NQA-1 or other nuclear industry standards. However, the culverts are manufactured in accordance with ASTM standards in ASTM C478 (Reference f). ASTM C4.78 (Reference f), and the atditional ASTM standards it references, provide testing and acceptance criteria for all phases of the construction process. Testing was performed by the culvert manufacturer, and satisfactory test results were provided to SWD. In addition, culvert design was reviewed and approved by a Washington state certified professional engineer. Taken together, these measures cover all the areas specified by Technical Position on Waste Form (Reference b). Therefore, the culvert was considerid to meet the quality assurance requirements in Technical Position on Waste Form (Reference b) Section 4.n.

\subsubsection{Summary}

The reinforced concrete culvert is considered approved as a HIC provided that the following restrictions are followed:

1. The culvert shall be used as a disposal container only, and will not be used to transport radioactive materials of any type.

2. Wastes which require subsequent inspections of any type shall not be placed in the culvert.

3. Gas generating waste will be evaluated on a case-by-case basis.

4. When used for contact-handled waste disposal, the culvert lid shall be sealed using epoxybased adhesive.

\subsection{Reinforced Concrete Vault}

A discussion of reinforced concrete vault compliance with NRC requirements and guidance is included in this section.

\subsubsection{Free Liquid}

Free liquids are prohibited from disposal in the LLBG by WHC-EP-0063 (Reference a), and by extension are prohibited from disposal in the vaults. Therefore, the vault was considered to meet the free liquid requirements in Technical Position on Waste Form (Reference b) Section 4.a.

\subsubsection{Design Life}

Technical Position on Waste Form (Reference b) and NRC Technical Evaluation Report "Multi-Use Container - High Integrity Container" (Reference c) specify a design lifetime of 300 years. The vault statement of work in Appendix B details the myriad design features incorporated to meet the 300 year design life goal. Each of these features are discussed in greater detail in following sections and are not duplicated here. Taken together, these features produced a design life as long as is reasonably achievable, and which should be well in excess of the 300 year goal. Therefore, the vault was considered to meet the design life requirements in Technical Position on Waste Form (Reference b) Section 4.b. 


\section{WHC-SD-WM-TI-761 Rev. 0}

\subsubsection{Corrosive and Chemical Effects}

The vault design considered corrosive and chemical effects from both the waste contents and the disposal environment. Since most chemicals which are detrimental to concrete are liquid and/or hazardous, and as a result are excluded from the LLBG by WHC-EP-0063 (Reference a), the radioactive waste contents pose little danger to the vault.

The greatest threat to the vault was from disposal environment agents, specifically ground water with dissolved sulfates, oxygen, and chlorides. The container was protected against these agents by the following design features:

1. Sulfate-resistant Type I/II portland cement was useil to limit sulfate attack.

2. Class $\mathrm{F}$ fly ash was included in the concrete mix to increase concrete density and improve resistance to sulfate attack.

3. A low water-cement ratio concrete mixture was used, which provides high density, low permeability concrete. Low permeability helps prevents sulfate attack on the concrete matrix and corrosion of encased reinforcement.

4. Only low chloride concrete mix constituents were used, to minimize the free chloride available to react with encased rebar.

5. Concrete cover of 2 inches was provided for all encased rebar, which limits access of water, oxygen and chloride to any steel structural components.

6. Exterior surfaces of the concrete were coated with an epoxy sealant to limit migration of water and dissolved chemicals through the concrete.

7. Air entrainment was added to improve sulfate and frezze-thaw resistance of the concrete.

8. Development of micro-cracks in the concrete matrix was minimized by use of steel fiber reinforcement, proper consolidation of the concrete, moist curing, and mechanical strength overdesign.

Taken together, these design features produced a highly degradation-resistant structure. Therefore, the vault was considered to meet the corrosion and chemical resistance requirements in Technical Position on Waste Form (Reference b) Section 4.c.

\subsubsection{Mechanical Strength}

The vault design considered static loads from soil overburden and backfill, as well as dynamic loads from waste handling, and disposal site operations. Tile vaut was designed in accordance with Uniform Building Code (UBC) requirements for reinforced concrete structures, which produced a robust design with significant safety margins. Therefore, the vault was considered to rneet the mechanical strength requirements in Technical Position on Waste Form (Reference b) Section 4.d.

\subsubsection{Thermal Resistance}

The vault design considered the effects of thermal loads. Section 4.6.6 of NRC Technical Evaluation Report "Multi-Use Container - High Integrity Container" (Feference c) discusses previous thermal 
cycling test results on concrete materials. Such testing has shown no significant changes in concrete design properties following thermal cycling, and as a result, additional thermal cycling testing was not required for the concrete.. Therefore, the vault was considered to meet the thermal resistance requirements in Technical Position on Waste Form (Reference b) Section 4.f.

\subsubsection{Radiation Resistance}

The vault design considered the radiation stability of the container materials. Appendix A, Section II.D of Technical Position on Waste Form (Reference b) discusses previous irradiation testing results on concrete materials. Such testing has shown no significant changes in concrete design properties at exposure levels past $10^{8}$ Rads. As a result, additional irradiation testing was not required for the concrete.

The epoxy coating material was also selected for resistance radiation exposure. The epoxy manufacturer's radiation testing data has shown no significant changes in design properties at exposure levels up to $10^{8} \mathrm{Rads}$. As a result, additional irradiation testing was not required for the epoxy coating material. Taken together, the existing irradiation testing data clearly demonstrate the radiation resistance of the vault design. Therefore, the vault was considered to meet the radiation resistance requirements in Technical Position on Waste Form (Reference b) Section 4.g.

\subsubsection{Biodegradation Resistance}

The vault design considered the biodegradation properties of the container materials. Appendix A, Section II.E of Technical Position on Waste Form (Reference b) discusses previous biodegradation testing results on concrete materials. Such testing has shown no significant changes in design properties following exposure to microorganisms in accordance with ASTM G21 and G22.

There are, however, several classes of microorganisms which have been shown to degrade concrete by giving off acidic waste products. Unfortunately, no standard test method exists to quantify the effects of such microorganisms. To minimize the potential for damage to the vault by all microorganisms, the organic carbon content in the cement matrix was limited to $1 \%$. By limiting the potential food source in the concrete matrix, the growth of microorganisms in the vicinity of the cement matrix will be strictly limited. Furthermore, the concrete will be shielded from any acidic waste products by the epoxy coating. Therefore, the vault was considered to meet the biodegradation resistance requirements in Technical Position on Waste Form (Reference b) Section 4.h.

\subsubsection{DOT Type A Testing}

Since the vault will be used as a disposal container only, DOT Type A testing was waived by the vault statement of work in Appendix A. As a result, the vault design does not meet the DOT Type A requirements in Technical Position on Waste Form (Reference b) Section 4.i. As discussed in Section 2.3.13, restrictions were placed on vault use for stabilization of Category 3 waste to account for this shortcoming.

\subsubsection{Water Collectic: =- Potantion}

The vault was designed to avoid collection and retention of water on its top surfaces. As shown in Appendix B, the vault lid is flat. Therefore, the vault was considered to meet the water collection and retention requirements in Technical Position on Waste Form (Reference b) Section 4.k. 


\subsubsection{Closure System}

For remote-handled waste, the vault lid is not sealed with epoxy-based adhesive. As a result, the vault does not meet the closure system requirements in Teshnical Position on Waste Form (Reference b) Section 4.1. Use of epoxy-based adhesive is not required for remote-handled waste in order to minimize personnel exposure. Given the low soil moisture content in Hanford soil anit the geometry of the container, there is very little potential for water infiltration through the unsealed joint. The potential threat from release of radionuclides due to this limited water infiltration was considered to be far less that the threat from personnel exposure during sealing operations. Therefore, no restrictions associated with sealing were placed on vault use for stabilization of remote-handled Category 3 waste.

For contact-handled waste, the vault was designed to provide positive closure by sealing all joints with an epoxy-based adhesive, but does not allow for inspection of the contents or for use of a vent to release gas generated by the waste. As a result, the vault does not meet the closure system requirements in Technical Position on Waste Form (Reference b) Section 4.1. As discussed in Section 2.3.13, restrictions were placed on vault use for stabilization of Category 3 waste to account for this shortcoming.

\subsubsection{Prototype Testing}

Prototype testing was waived by Appendix B. As a result the vault does not meet the prototype testing requirements in Technical Position on Waste Form (Reference b) Section 4.m.

However, as discussed in Section 4.6.9 of NRC Technical Evaluation Report "Multi-Lise Container High Integrity Container" (Reference c), the principal reason the NRC requires prototype testing for HICs is to support DOT Type A qualification. This is because the response of a container to complex dynamic loads incurred during drop testing and other accident scenarios is exceedingly difficult to model. Loading of concrete structures under burial conditions, on the other hand, can be accurately modeled and is supported by a wealth of past design experience. Therefore, satisfactory mechanical strength was considered to be adequately demonstrated by conservative engineering design alone.

\subsubsection{Quality Assurance}

The vault manufacturer was not required to maintain a quality assurance program meeting NQA-1 or other nuclear industry standards. However, the vaults are manufactured in accordance with ASTM standards in ASTM C478 (Reference f). ASTM C478 (Reference f), and the additional ASTM standards it references, provide testing and acceptance criteria for all phases of the construction process. Testing was performed by the vault manufacturer, and satisfactory test resultis were provided to SWD. In addition, vault design was reviewed and approved by a Washington state certified professional engineer. Taken together, these measures cover all the areas specified by Technical Position on Waste Form (Reference b). Therefore, the vault was considered to meet the quality assurance requirements in Technical Position on Waste Form (Reference b) Section 4.n.

\subsubsection{Summary}

The reinforced concrete vault is considered approved as a HIC provided that the following restrictions are followed:

1. The vault shall be used as a disposal container only, and will not be used to transport radioactive materials of any type. 
WHC-SD-WM-TI-761 Rev. 0

2. Wastes which require subsequent inspections of any type shall not be placed in the vault.

3. Gas generating waste will be evaluated on a case-by-case basis.

4. When used for contact-handled waste disposal, the vault lid shall be sealed using epoxy-based adhesive.

\subsection{References}

(a) WHC-EP-0063, current revision, Hanford Site Waste Acceptance Criteria, Westinghouse Hanford Company, Richland, WA.

(b) Technical Position on Waste Form, Revision 1, January 1991, United States Nuclear Regulatory Commision, Office of Nuclear Material Safety and Safeguards, Washington, D.C.

(c) NRC Technical Evaluation Report "Multi-Use Container - High Integrity Container", Rev 1, April 1995, United States Nuclear Regulatory Commision, Office of Nuclear Material Safety and Safeguards, Washington, D.C.

(d) WHC-HS-V-P-0036, current revision, High Integrity Container, 300 Year, Westinghouse Hanford Company, Richland, WA.

(e) VECTRA 95 Drum Concrete High Integrety Container Design Report, Rev 1, February 1995, VECTRA Technologies, Inc., Federal Way, Washington.

(f) ASTM C478, Standard Specification for Precast Reinforced Concrete Manhole Sections, American Society of Testing and Materials. 
WHC-SD-WM-TI-76! Rev. 0

\author{
Appendix A: \\ Statement of Work \\ Reinforced Concrete Culvert With Nested Lid
}


WHC-SD-WM-TI-761 Rev. 0

Intentionally Blank

A-ii 
WHC-SD-WM-TI-761 Rev. 0

\author{
Statement of Work \\ Reinforced Concrete Culvert With Nested Lid
}

November 9, 1995

\title{
1.0 Construction Methods
}

Culverts shall be constructed in accordance with Figure 1. The design and construction methods of WS DOT/APWA Standard Plan B 24 and ASTM C 478 shall be followed, with the following additions and modifications.

\subsection{Dimensions}

The culvert dimensions listed in Figure 1 may be adjusted by the Seller as required by WS DOT/APWA Standard Plan B 24, ASTM C 478, or to conform with standard tooling at the Seller's facility, provided that:

- The payload volume of the culvert shall be a minimum of 7 feet high by 8 feet in diameter.

- The culvert lid shall be a minimum of 2 feet thick.

\subsection{Lifting Attachments}

Lifting attachments for the body of the culvert shall use carbon steel coil inserts or equivalent. The Seller shall provide calculations to show that the lifting attachments provide a $3: 1$ factor of safety based on yield strength or 5:1 factor of safety based on ultimate strength, whichever is greater.

Lifting attachments for the lid of the culvert shall use wire rope or equivalent. The wire rope lifting devices shall be designed in accordance with the requirements of the PCI Design Handbook. The applicable section of the PCI Design Handbook has been included as Attachment 1.

Any lifting attachment design which requires a hole completely through any part of the culvert shall be disqualified.

\subsection{Materials}

Each culvert shall be constructed using steel fiber-reinforced concrete. The concrete shall be prepared in accordance with ASTM C 1116. Proportioning alternative 1 (purchaser assumes responsibility for mixture proportions) shall be used. Ordering information is as follows:

\subsubsection{Cement}

The cuivert shall be constructed using Type II or Type I/II sulfate resistant Foriariu cement. The cement shall be in accordance with ASTM C 150. Nominal water-tocement ratio shall be 0.4 . 


\subsubsection{Pozzolan}

Nominal fly ash content shall be $15 \%$ of the cement volume. Class $F$ fly ash shall be used in accordance with ASTM C 618.

\subsubsection{Aggregates}

Aggregates shall be in accordance with ASTM C 33. Coarse aggregate shall be ASTM size No. 67 or equivalent ( $3 / 4$ in nominal). Fine aggregate shall be sand. Reactive aggregates shall be excluded in accordance with ASTM C 33 Appendix XI and ASTM C 289.

Aggregates with demonstrated good freeze-thaw performance shall be used if available. If no past performance information is available on the aggregates, freezethaw testing in accordance with ASTM C 666 shall be conducted.

\subsubsection{Workability}

Normal or high-range water reducers shall be used as needed to obtain the desired workability. Water reducers shall be used in accordance with the manufacturer's directions.

\subsubsection{Air Content}

Entrained air shall be $6 \% \pm 1.5 \%$. Air eritrainment admixtures shall be used in accordance with the manufacturers directions to obtain the specified air content.

\subsubsection{Fiber}

Steel fiber shall be in accordance with ASTM A 820. The following ordering information shall be used for procurement.

a) Type I (cold drawn wire) shall be used.

b) Nominal length shall be from 1.0 to 1.5 inch.

c) Tensile strength shall be $150,000 \mathrm{psi}$ minimum.

d) Aspect Ratio (length/diameter) shall be from 60 to 100 .

e) Deformed fiber shall be used.

\subsubsection{Chloride}

Cement, aggregates, admixtures and mix water shall be controiled to limit soluble chloride ion concentration in the concrete mixture to less than $0.1 \%$ by weight in accordance with ACI 201.2R.

\subsubsection{Organic Carbon}

Cement, aggregates, admixtures and mix water shall be controlled to limit organic ca-bon concentration in the concrete mixture to liss than $1 \%$ by weight. 
WHC-SD-WM-TI-76I Rev. 0

\subsubsection{Proportions}

Concrete for culvert construction shall be prepared using the nominal proportions in Table 1. Variations in proportions may be made to account for actual aggregate densities and field conditions.

\subsubsection{Batching, Mixing and Transportation}

Concrete shall be batched, mixed and transported in accordance with ASTM C 1116 and the steel fiber manufacturer's directions.

\subsection{Acceptance}

Compression tests for acceptance of culvert risers and bases shall be performed on standard cylinders prepared in accordance with ASTM C 31 or ASTM C 192. Compression test specimens shall not be prepared by drilling cores from culvert sections.

Acceptance of the culvert top shall be based on rational design. The top must withstand a load equivalent to 16 feet of soil overburden at a soil density of $120 \mathrm{lbs} / \mathrm{ft}^{3}$. The Seller shall submit design drawings and calculations for review and approval by the Buyer.

\subsection{Coating}

The culvert shall be coated using an epoxy sealant on all exterior surfaces. The coating material shall be applied in accordance with the manufacturer's directions.

\subsection{Manufacturer Documentation}

The manufacturer shall provide documentation with delivery including:

a) The resuits of all tests, both in the laboratory and in the field, performed during construction of the culvert.

b) The results of all field inspections performed during construction of the culveit.

c) A detailed description of the exact cement formulation used, including water reducers and air entrainment additives. 
WHC-SD-WM-TI-761 Rev. 0

Table 1. Nominal Concrete Mixture Proportions

\begin{tabular}{||l|c|}
\hline \multicolumn{1}{|c|}{ Material } & Proportion \\
\hline Cement & $642 \mathrm{lbs} / \mathrm{yd}^{3}$ \\
\hline Fly Ash & $91 \mathrm{lbs} / \mathrm{yd}^{3}$ \\
\hline Coarse Aggregate & $55 \%$ by vol \\
\hline Fine Aggregate & $45 \%$ by vol \\
\hline Water & $305 \mathrm{lbs} / \mathrm{yd}^{3}$ \\
\hline Steel Fiber & $100 \mathrm{lbs} / \mathrm{yd}^{3}$ \\
\hline
\end{tabular}




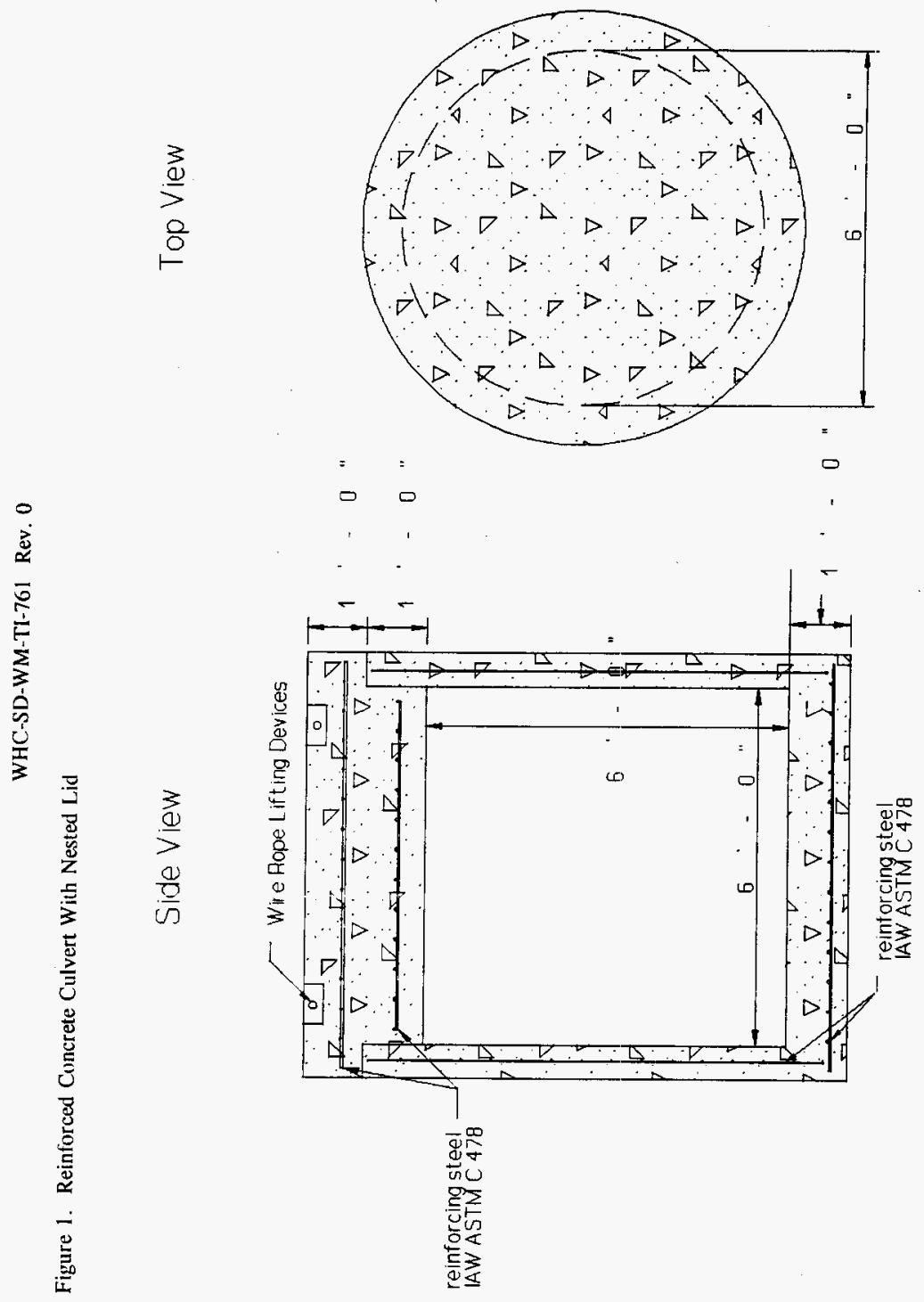


WHC-SD-WM-TI-76I Rev. 0

Intentionally Blank 
WHC-SD-WM-TI-761 Rev. 0

\author{
Appendix B: \\ Statement of Work \\ Reinforced Concrete Vault With Lid
}


WHC-SD-WM-TI-761. Rev. 0

Intentionally Blank

B-ii 


\section{WHC-SD-WM-TI-76॥ Rev. 0 \\ Statement of Work \\ Reinforced Concrete Vault With Lid}

December 6, 1995

\subsection{Introduction}

The Buyer requires rectangular reinforced concrete vaults to serve as burial containers for various sizes of boxes containing radioactive waste. The vaults shall incorporate the design and construction features described in this statement of work to maximize service life and minimize water infiltration in a burial environment.

\subsection{Sequence of Events}

The following sequence of events describes the intended use of the vaults:

1. The empty vault body (without lid) will be placed on the floor of an excavated trench.

2. The desired box(es) of waste will be placed by crane into the vault body.

3. Void fill materials (sand, etc.) will be loosely placed into the void spaces between the waste box and the walls of the vault. Void fill materials will be arranged to allow unimpeded installation of the vault lid.

4. Adhesive material will be applied to the mating surfaces of the lid and vault body in accordance with the adhesive manufacturer's directions.

5. The lid will be glued onto the vault body.

6. The trench will be backfilled using standard excavation techniques.

\subsection{Construction Methods}

Vaults shall be constructed in accordance with the following requirements. A concept sketch of the vault is shown in Figure 1.

\subsection{Design Loads}

The vault base and lid shall be designed to withstand an external load of $3800 \mathrm{lbf} / \mathrm{ft}^{2}$. No credit shall be taken for the load carrying capability of the void fill materials.

The vault sides shall be designed to withstand an average external load of $1150 \mathrm{lbf} / \mathrm{ft}^{2}$. No credit shall be taken for the load carrying capability of the void fill materials. The vault walls shall also be designed to withstand an internal load equivalent to filling the payload volume of the vault with sand at a density of $120 \mathrm{Ibf} / \mathrm{ft}^{3}$.

The above design loads take into account loads from depth of burial and operation of 


\section{WHC-SD-WM-TI-761 Rev. 0}

construction equipment over and around the buried vaults. No additional design loads need be applied.

\subsection{Compressive Strength}

The concrete mixture described in Section 3.5 has been shown to exhibit a 28 day compressive strength in excess of $5000 \mathrm{psi}$. A conservative value of $4000 \mathrm{psi}$ shall be used for vault design.

Compression tests for acceptance of the vault shall be performed on standard cylinders prepared in accordance with ASTM C 31 or ASTM C 192.

\subsection{Dimensions}

The vault shall be designed with a payload volume measuring at least $10^{\prime}-6^{\prime \prime}$ long by $7^{\prime}$ wide by 9 ' -6 " tall. Vaults larger than the minimum required to accommodate the above payload volume shall be considered acceptable to allow for use of existing tooling and formwork.

\subsection{Lifting Attachments}

Lifting attachments for the body of the vault shall use carbon steel coil inserts or equivalent. The lifting attachments shall be designed to move the body of the vault when empty. The Seller shall provide calculations to show that the lifting attachments provide a 3:1 factor of safety based on yield strength or 5:1 factor of safety based on ultimate strength, whichever is greater.

Lifting attachments for the lid of the vault shall use wire rope or equivalent. The wire rope lifting devices shall be designed in accordance with the requirements of the PCI Design Handbook. The applicable section of the PCI Design Handbook has been included as Attachment 1.

Any lifting attachment design which requires a hơle cumpleteily through any part of the vauit shall be disqualified.

\subsection{Materials}

Each vault shall be constructed using steei fioer-reiniorced concrete. The concrete shail be prepared in accordance with ASTM C 1116. Proportioning alternative 1 (purchaser assumes responsibility for mixture proportions) shall be used. Ordering information is as follows:

\subsubsection{Cement}

The vault shall be constructed using Type II or Type I/II sulfate resistant Portland cement. The cement shall be in accordance with ASTM C 150. Nominal water-tocement ratio shall be 0.4 . 


\subsubsection{Pozzolan}

Nominal fly ash content shall be $15 \%$ of the cement volume. Class F fly ash shall be used in accordance with ASTM C 618.

\subsubsection{Aggregates}

Aggregates shall be in accordance with ASTM C 33. Coarse aggregate shall be ASTM size No. 67 or equivalent ( $1 / 4$ in nominal). Fine aggregate shall be sand. Reactive aggregates shall be excluded in accordance with ASTM C 33 Appendix XI and ASTM C 289.

Aggregates with demonstrated good freeze-thaw performance shall be used if available. If no past performance information is available on the aggregates, freezethaw testing in accordance with ASTM C 666 shall be conducted.

\subsubsection{Workability}

Normal or high-range water reducers shall be used as needed to obtain the desired workability. Water reducers shall be used in accordance with the manufacturer's directions.

\subsubsection{Air Content}

Entrained air shall be $6 \% \pm 1.5 \%$. Air eritrainment admixtures shall be used in accordance with the manufacturers directions to obtain the specified aic content.

\subsubsection{Fiber}

Steel fiber shall be in accordance with ASTM A 820. The following ordering information shall be used for procurement.

a) Type I (cold drawn wire) shall be used.

b) Nominal length shall be from 1.0 to 1.5 inch.

c) Tensile strength shall be $150,000 \mathrm{psi}$ minimum.

d) Aspect Ratio (length/diameter) shall be from 60 to 100 .

e) Deformed fiber shall be used.

\subsubsection{Chloride}

Cement, aggregates, admixtures and mix water shall be controlled to limit soluble chloride ion concentration in the concrete mixture to less than $0.1 \%$ by weight in accordance with ACI 201.2R.

\subsubsection{Organic Carbon}

Cement, aggregates, admixtures and mix water shall be controlled to limit organic carbon concentration in the concrete mixture to less than $1 \%$ by weight. 


\subsubsection{Proportions}

Concrete for vault construction shall be prepared using the nominal proportions in Table 1. Variations in proportions may be made by the Seller to account for actual aggregate densities and field conditions.

\subsubsection{Batching, Mixing and Transportation}

Concrete shall be batched, mixed and transported in accordance with ASTM C 1116 and the steel fiber manufacturer's directions.

\section{$4.0 \quad$ Void Fill}

The vault design shall allow for void spaces between the vault and the waste box to be filled with sand or other inert material following placement of the waste box into the vault. The void fill criteria used by the Buyer is $>90 \%$ full. Void fill materials will be loosely placed into the void spaces, and will not be compacted after placement. Void fill operations will be completed prior to installation of the lid.

\subsection{Coating}

The vault and lid shall be coated using an epoxy material on all exterior surfaces. The best available epoxy coating material shall be used. The coating material shall be applied in accordance with the manufacturer's directions.

\subsection{Sealing}

The vault shall be designed so that the lid can be permanently bonded to the base using an epoxy adhesive material during final assembly. Sufficient epoxy adhesive material shall be supplied by the Seller to seal all the vaults. The best available epoxy adhesive material shall be used.

\subsection{Miscellaneous Notes}

The vaults are not considered secondary containment structures.

The vaults will be buried well above the local water table, and therefore do not need to be designed for submerged service.

\subsection{Manufacturer Documentation}

\subsection{Proposal}

The Seller shall provide documentation with the proposal including:

a) Design drawings, data and calculations. 


\section{WHC-SD-WM-TI-761 Rev. 0}

\subsection{Delivery}

The Seller shall provide documentation prior to delivery including:

a) The results of all tests, both in the laboratory and in the field, performed during construction of the vault.

b) The results of all field inspections performed during construction of the vault.

c) A detailed description of the exact cement formulation used, including water reducers and air entrainment additives.

d) Adhesive material application and assembly instructions.

Table 1. Nominal Concrete Mixture Proportions

\begin{tabular}{|l|l|}
\hline \multicolumn{1}{|c|}{ Material } & Proportion \\
\hline Cement & $642 \mathrm{lbs} / \mathrm{yd}^{3}$ \\
\hline Fly Ash & $91 \mathrm{lbs} / \mathrm{yd}^{3}$ \\
\hline Coarse Aggregate & $55 \%$ by vol \\
\hline Fine Aggregate & $45 \%$ by vol \\
\hline Water & $305 \mathrm{lbs} / \mathrm{yd}^{3}$ \\
\hline Steel Fiber & $100 \mathrm{lbs} / \mathrm{yd}^{3}$ \\
\hline
\end{tabular}




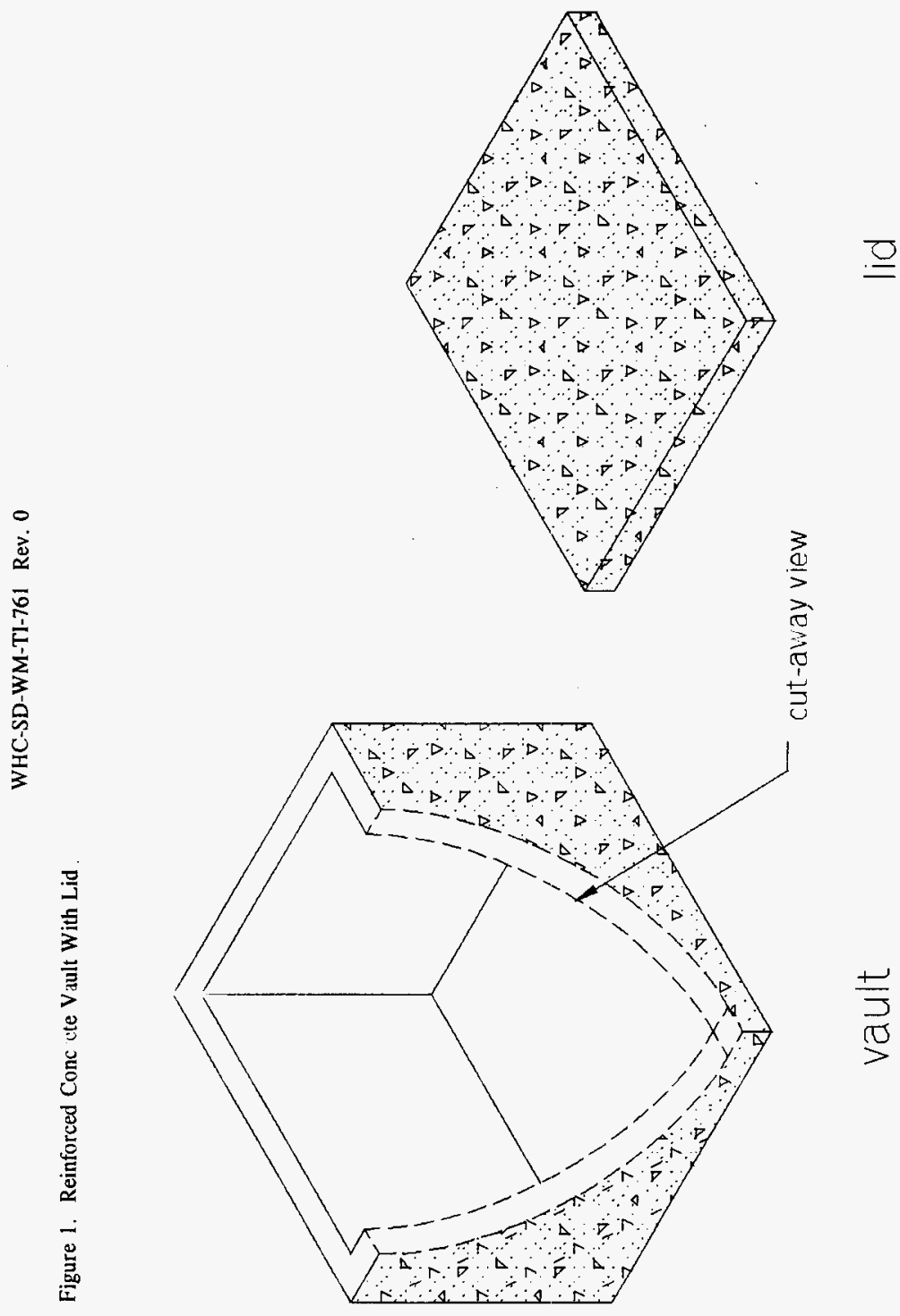

